\title{
Крым-сагыз - полузабытый каучуконос и его латинские названия
}

\author{
(C) А.М. Сагитов ${ }^{1}$, Б.Р. Кулуев ${ }^{2}$, А.В. Чемерис ${ }^{2}$ * \\ ${ }^{1} \mathrm{OOO} \mathrm{Рост-Консалт}$ \\ Россия, Республика Башкортостан, 450000, Уфра, ул. Крупской, 9 \\ ${ }^{2}$ Институт биохимии и генетики - обособленное структурное подразделение Феде- \\ рального государственного бюджетного научного учреждения Уфимского фредераль- \\ ного исследовательского центра Российской академии наук \\ Россия, Республика Башкортостан, 450054, Уфра, пр. Октября, 71 \\ *Email: chemeris@anrb.ru \\ О том, что оказавшийся почти забытым как каучуконос одуванчик осенний Taraxacum \\ hybernum Stev. или крым-сагыз может служить источником натурального каучука, было \\ выяснено лишь в 1931 г., хотя этот вид растений был известен задолго до этого, пре- \\ терпев множественные переименования латинских названий. Считается, что суще- \\ ствуют два близких вида - эндемик Крымского побережья T.hybernum, полный пла- \\ стидный геном которого нами недавно секвенирован, и распространенный по югу За- \\ падной Европы T.megalorhizon. Для уточнения взаимоотношений этих видов необхо- \\ димо секвенировать пластидный геном последнего.
}

Ключевые слова: крым-сагыз, одуванчик осенний, Taraxacum hybernum, каучуконос.

У большого числа растений с момента их открытия многими поколениями ботаников были многократно изменены их видовые и родовые названия. При этом часть из них стали относить к иным семействам и даже порядкам. И это вполне нормально, поскольку постоянно шел процесс познания, и в систематике растений происходили (преимущественно) вполне оправданные в конкретный момент времени изменения.

В данной публикации мы обратили внимание на отечественный каучуконос прошлого одуванчик осенний или крым-сагыз Taraxacum hybernum Stev., причем здесь для него приведено далеко не первое, но принятое в настоящее время в нашей стране наименование, хотя и некоторые прежние его латинские названия у ботаников, что называется в ходу. При этом на других территориях произрастания этого одуванчика они, возможно, относятся все же не к крым-сагызу, а к его ближайшим сородичам, что еще предстоит уточнить. При этом нужно заметить, что молекулярная геносистематика до этих видов пока не добралась, поскольку с ее помощью наверняка могли бы быть получены новые данные, проясняющие ситуацию.

Одуванчик крым-сагыз это свое название получил в начале 1930-х гг., после того как его каучуконосность установили украинские ботаники М.И.Котов и В.И.Черкасов [1], по аналогии с обнаруженными приблизительно в те же годы другими корневыми каучуконосами - тау-сагызом (Scorzonera tau-saghyz Lipsch. \& Bosse) и кок-сагызом (T.koksaghyz Rodin).

И здесь требуется небольшое отвлечение. В годы Великой Отечественной войны Котов не прекратил ботанические исследования и, будучи эвакуированным в составе 
Академии наук УССР в Уфру, изучал фрлору Башкирии, разработал ее ботаникогеографическое районирование, был инициатором и ведущим автором изданного в 1966 г. «Определителя растений Башкирской АССР», за что в 1967 г. получил почетное звание Заслуженного деятеля науки БАССР и в Башкирской энциклопедии о нем есть соответствующая статья, подготовленная другим известным ботаником Е.В. Кучеровым. Поэтому можно считать, что крым-сагыз и Башкортостан неким образом связаны между собой уже давно.

Вернувшись в начало 1930-х гг. нельзя обойти вниманием другую работу Котова и Черкасова [2], в которой они описывают как, «экскурсируя» поздней осенью 1931 г. в окрестностях Гурзуфа, около Никиты и вблизи Ялты, ими обнаружены цветущие одуванчики T.gymnanthum DC., довольно подробно коснувшись в этой статье вопросов систематики данного вида. Ранее отечественным ботаникам этот вид был также известен как одуванчик осенний T.hybernum, описанный в 1856 г. директором-основателем Никитского ботанического сада россиянином, шведом по происхождению Х.Стевеном [3]. Эта его публикация вышла в являющемся в настоящее время старейшим отечественным журналом по естествознанию - Бюллетене Московского общества испытателей природы, называвшимся тогда по-французски Bulletin de la Societe Imperiale des Naturales de Moscou. Но за столетие до этого в начале 1760-х гг. подающий большие надежды ученик К.Линнея P.Forskål, путешествуя по Египту и Ближнему Востоку, описал этот или другой очень близкий к нему вид, назвав его Leontodon megalorhizos Forsk., что, в том числе, свидетельствовало о его крупных корнях. Однако публикация с описанием L.megalorhizos вышла только в 1775 г. после смерти Forskål (наступившей в раннем возрасте от малярии), подготовленная единственным выжившим участником той экспедиции C.Niebuhr [4]. Котов и Черкасов [2] упоминают, что еще более раннее название этого растения было L.minimum Brig., но на web-pecypce List of botanists by author abbreviation (https://en.wikipedia.org/wiki/List of botanists by author abbreviation), где приведены фрамилии наиболее значимых ботаников всего мира с присущими им аббревиатурами на странице V.Briganti https://species.wikimedia.org/wiki/Vincenzo Briganti говорится, что нет растений, описанных этим итальянским ботаником, хотя эти сведения могут быть не очень верны. В той же своей статье 1933 г. [2] Котов и Черкасов пишут, что в Европе этот вид одуванчика известен также под латинскими названиями T.autumnale Cost., T.humiusum Heldr., T.micranthum DC. Но это еще не все синонимы одного и того же или очень близких видов одуванчика. И на некоторых из них мы далее более подробно остановимся.

В 1822 г. был описан новый, близкий к нынешнему крым-сагызу вид (возможно, тот же самый), названный L.daedaleus Sieber; в 1832 г. сочли, что нужно выделить вид L.gymnanthus Link., а чуть позже в 1838 г. он был переименован в T.gymnanthum (Link.) DC. Наконец, Стевен на другой территории, а именно в Крыму описал этот вид как T.hybernum, о чем мы уже говорили выше. Но на этом переименования данного одуванчика или близкого к нему вида, либо параллельное использование его/их разных названий не закончились. В третьем томе Flora Orientalis 1875 г. издания [5] приводятся несколько видов одуванчиков, которые могут нас интересовать. Так, помимо T.gymnanthum, про который говорится, что его синонимом является T.hybernum, упоминается также T.officinale ssp. laevigatum Bisch. Cich., и о нем сообщается, что он цветет осенью и имеет более толстое корневище, что совпадает с признаками крымсагыза. Однако про нынешний вид T.laevigatum (Willd.) DC. (https://pfaf.org/user/Plant.aspx?LatinName=Taraxacum+laevigatum) сейчас можно прочесть, что он распространен в Европе, но цветет с апреля по июнь.

В конце XIX столетия вышло «Руководство для определения семенных и высших споровых растений фрлоры средней и южной России, Крыма и Северного Кавказа» за авторством И.Шмальгаузена [6], в котором во втором томе дается описание T.gymnanthum, про который говорится, что он имеет толстый корень, а местами его 
произрастания, кроме Крыма, указываются Южная Франция, Италия, Греция, Византия, Малая Азия, Сирия. Приводится также его синоним - T.hybernum. В 1907 г. L.megalorhizos стал называться T.megalorhizon (Forssk.) Hand.-Mazz., сменив не только родовое название, но и окончание видового имени; в 1913 г. посчитали, что нужно признать существование T.officinale subsp. gymnanthum (Link.) Cout. В статье [7], посвященной анализу природных ресурсов СССР в виде каучуконосов и гуттаперченосов, рассмотрен целый ряд видов таких растений, включая крым-сагыз, латинское наименование которого приведено в ней как T.megalorhizon. Таким образом, только для одуванчика, обитающего в Крыму, разными отечественными авторами в XX веке использовано три его латинских видовых названия - gymnanthum, hybernum и megalorhizon.

В настоящее время принято считать, что имеется два близких вида - T.megalorhizon, произрастающий преимущественно по югу Западной Европы (https://www.gbif.org/species/9643751), тогда как T.hybernum обитает на побережье Крыма. Однако в августе 1962 г. Е.Победимовой и В.Гладковой в окрестностях Севастополя в бухте Камышовой на глинисто-известняковом обрыве у моря был найден другой вид одуванчика, который описан Б.К.Шишкиным как T.pobedimoviae Schischk., про который в книге «Флора СССР» 1964 г. на стр. 531 под номером 160 говорится, что это «Р. 6 - 20 см. выс., с очень толстым (выделено нами), обычно многоглавым корнем» [8]. В том же издании под номером 159 фигурирует одуванчик T.hybernum, про который сказано, что это эндемичный вид для Крымского побережья и приведены его синонимы. Первым дан T.gymnanthum, в качестве другого синонима указан T.megalorhizon. При описании хозяйственного значения T.hybernum отмечается, что в его латексе содержится относительно большой процент каучука и что открыт он как каучуконос Котовым и Черкасовым в 1931 г. В книге «Флора Европейской части СССР» 1989 г. издания в томе VIII [9] под номерами 146 и 145 соответственно также приведены оба этих вида, но про T.pobedimoviae говорится, что его самостоятельность нуждается в подтверждении на более обильном материале.

Возвращаясь к одной из первых статей [2], в которых описывается каучуконосность T.gymnanthum (T.hybernum), нужно сказать, что Котов и Черкасов проявили вполне оправданный интерес к своему открытию и проанализировали насчитывающий не одно десятилетие гербарный материал, собранный задолго до них и хранящийся в Украинском Институте растениеводства. Так, ими были исследованы гербарные образцы того же вида одуванчика, собранные фон Граффом в 1860 г. в Крыму возле Никиты. Несмотря на 70-летнюю давность в их корнях сохранились нити каучука, которые легко очищались от древесины корня простым перетиранием его руками. В гербарии другого известного российского ботаника Н.С.Турчанинова, собранного им в Греции (Афины) и датированном 1851 г., тяжи каучука в корнях его одуванчика также были в отличной сохранности. Определив в собранных ими самими образцах крым-сагыза содержание смол и каучука, составившие около 3\% и 6-9\%, соответственно, Котов и Черкасов высказали предположение, что этот вид одуванчика может служить в качестве одного из источников натурального каучука в Советском Союзе [2], что позже и произошло. При этом серьезную конкуренцию крым-сагызу тогда составили другие корневые каучуконосы - тау-сагыз и в особенности кок-сагыз, как менее требовательный к теплому климату в отличие от крым-сагыза. Однако в 1930-1940-ые гг. в СССР велись также работы по доместикации крым-сагыза и были найдены несколько его фоорм - буросемянная, белосемянная и розовосемянная, характеризующиеся некоторыми отличиями в продукции каучука [10]. Но в начале 1950-х гг. выращивание каучуконосов в нашей стране закончилось, отчасти по причине восстановления поставок гевейного каучука из ЮгоВосточной Азии, но, главным образом, благодаря созданию новой технологии получения синтетического каучука. Однако следует отметить, что натуральный каучук обладает свойствами, которых пока не могут добиться химики-синтетики для искусственного каучука и поэтому спрос на натуральный каучук в мире в последние годы растет, поскольку он требуется для высококачественных шин, в том числе для большегрузных 
автомобилей и особенно для авиационной промышленности. Поэтому в настоящее время, интерес к кок-сагызу как каучуконосу возрождается в разных странах, тогда как крым-сагыз оказался практически позабыт. Кроме нас [11 - 13] крым-сагызом, можно сказать, никто в мире не интересуется. И напрасно. Нами с коллегами в Крыму заново найдены его буросемянная и розовосемянная фрормы. Белосемянную пока найти не удалось. Поскольку T.hybernum является апомиктичным видом и подвержен незначительной изменчивости нами проведены эксперименты по выявлению полиморфизма его ДНК $[14,15]$, которые будут продолжены. Нами также секвенирован полный пластидный геном крым-сагыза размером 151279 п.н., сравнительный анализ которого показал, что этот вид достаточно близок к кок-сагызу и удален от одуванчика лекарственного (статья готовится к печати). Для прояснения родства T.hybernum и T.megalorhizon необходимо секвенировать пластидный геном последнего, что даст однозначный ответ насколько эти виды близки или самостоятельны, поскольку геномы хлоропластов достаточно консервативны в эволюции.

\section{Литература}

1. Котов М.И., Черкасов В.Т. Новое каучуконосное растение - одуванчик осенний // Советский каучук. 1932. № 4. С. 26-28.

2. Котов М., Черкасов Вл. Новое каучуконосное растение - одуванчик осенний (Taraxacum gymnanthum D.C.), произрастающее на Южном берегу Крыма // Природа. 1933. № 2. C.63-65.

3. Steven C. Verzeichniss der auf der taurischen Halbinsel wildwachsenden Pflanzen // Bulletin de la Societe Imperiale des Naturales de Moscou. 1856. T.29. No.4. P.339-418.

4. Forskål P. Flora Aegyptiaco-Arabica sive Descriptiones Plantarum, quas per Aegyptum Inferriorem et Arabian Felicem detexit, Illustravit Petrus Forskål prof. Haun. post morten Auctoris editit Carsten Niebuhr. 1775.

5. Boissier E. Flora Orientalis sive Enumeratio Plantarum in Oriente a Grecia et Aegypto ad indle fines Hucusque Observatarum. Volmen Tertium. 1875.

6. Шмальгаузен И. Флора Средней и южной России, Крыма и Северного Кавказа. Руководство для определения семенных и высших споровых растений. 1898. Т.2.

7. Лапин А.К. Каучуконосы и гуттаперченосы СССР // Природа. 1936. №7. С.110-123.

8. Флора СССР. 1964. Т.29.

9. Флора европейской части СССР. 1989. Т.8.

10. Филиппов Д.И., Ничипорович А.А., Аксельрод Д.М. Культура каучуконосов в СССР // М., Сельхозгиз. 1948. 359 С.

11. Кулуев Б.Р., Картуха А.И., Князев А.В., Фатерыга А.В., Чемерис А.В. Опыт выращивания Taraxacum hybernum (Asteraceae) // Растительные ресурсы. 2017. №4. C.543-554.

12. Knyazev A., Kuluev B., Fateryga A. Yasybaeva G., Chemeris A. Aseptic germination and Agrobacterium rhizogenes mediated transformation of Taraxacum hybernum Steven // Plant Tissue Culture and Biotechnology. 2017. V. 27, P. 141-151. 
13. Гаршин М.В., Кулуев Б.Р. Крым-сагыз: Особенности растения, перспективы возделывания и селекция (Обзор) // Аграрная Россия. 2018. №4, С.40-48.

14. Кулуев Б.Р., Фатерыга А.В., Кулуев А.Р., Михайлова Е.В., Чемерис А.В. Молекулярно-генетическое исследование одуванчика осеннего (Taraxacum hybernum Steven) с использованием SSR, RAPD и ISSR-маркеров // Вавиловский журнал генетики и селекции. 2018. Т.22. №1. С. 102-107.

15. Bari G., Gainullina K.P., Gumerova G.R., Uteulin K.R., Golovanov Ya., Chemeris A.V., Kuluev B.R. Multilocus DNA polymorphism of some rubber-bearing dandelions (Taraxacum spp.) of Russia and Kazakhstan // Genet Resour Crop Evol. 2021. https://doi.org/10.1007/s10722-021-01233-1

\title{
Krym-saghyz - half-forgotten rubber-bearing plant and its Latin names
}

\author{
A. M. Sagitov ${ }^{1}$, B. R. Kuluev², A. V. Chemeris ${ }^{2}$ * \\ ${ }^{1}$ Rost-Consult LLC \\ 9 Krupskaya str. 450000, Ufa, Republic of Bashkortostan, Russia
}

${ }^{2}$ Institute of Biochemistry and Genetics - Subdivision of the Ufa Federal Research Centre of the Russian Academy of Sciences

71 Prospect Oktyabrya, 450054, Ufa, Republic of Bashkortostan, Russia

*Email: chemeris@anrb.ru

The fact that the almost forgotten as rubber-bearing plant dandelion Taraxacum hybernum Stev. or Krym-saghyz can serve as a source of natural rubber was found out only in 1931, although this plant species was known long before that, having undergone multiple renaming of Latin names. Now there are two close species - T. hybernum, endemic to the Crimean coast, the full plastid genome of which we have recently sequenced, and T. megalorhizon, distributed in the south of Western Europe. To clarify the relationship of these species, it is necessary to sequence the plastid genome of the latter.

Keywords: Krym-saghyz, dandelion, Taraxacum hybernum, rubber-bearing plant. 